\title{
Analisa Rantai Pasok Komoditas Tembakau Madura
}

\author{
Faikul Umam ${ }^{1 *}$, Ari Basuki², Firmansyah Adiputra ${ }^{3}$ \\ 1,2,3 Universitas Trunojoyo Madura \\ *faikul@trunojoyo.ac.id
}

DOI: http://dx.doi.org/10.21107/rekayasa.v12i1.5298

\begin{abstract}
ABSTRAK
Komoditas tembakau Madura merupakan salah satu komoditas perkebunan yang yang banyak dibudidayakan oleh petani Madura. Akan tetapi pada kenyataannya, petani tembakau madura masih belum bisa menjual tembakaunya dengan harga yang tinggi. Ini dikarenakan panjangnya rantai pasok penjualan tembakau Madura. Terdapat beberapa interrmediate trader dalam rantai pasok tersebut dan setiap intermediate trader juga mengambil keuntungan penjualan. Penelitian ini bertujuan untuk memperbaiki mekanisme rantai pasok penjualan tembakau Madura. Metode yang digunakan pada penelitian ini yaitu analisa SWOT dan analisa rantai pasok. Data diperoleh dengan melakukan FGD dan wawancara. Hasil penelitian berupa rekayasa rantai pasok penjualan komoditas tembakau dengan menciptakan marketplace. Diharapkan penelitian ini bisa menjadi input bagi penelitian selanjutnya dalam proses desain dan membangun marketplace.
\end{abstract}

Kata Kunci: tembakau madura, SWOT, rantai pasok, marketplace

Supply Chain Analysis of Madura Tobacco Commodities

\section{ABSTRACT}

Product of Madura tobacco is one of the plantation commodities which is widely cultivated by Madurese farmers. In fact, though Madura tobacco farmers still could not sell their tobacco at a higher price. This is due to the supply chain of Madura tobacco sales which has a long network. There are several intermediate traders in the supply chain network and each intermediate trader takes sales profits as well. This research aims to analyze and remodel the supply chain mechanism for Madura tobacco sales. This study employed a SWOT analysis and supply chain analysis. Data were obtained by conducting FGDs and interviews. The research results from a new model of the sales supply chain for Madura tobacco by creating a marketplace. It is expected that this work can be useful as an input for further study in designing and building a marketplace.

Keywords: Madura tobacco, SWOT, supply chain, marketplace

\section{PENDAHULUAN}

Tembakau merupakan salah komoditas perkebunan Indonesia yang menempati urutan ketiga (setelah kelapa dan tebu) dalam hal luasan area produksi (https://disbun. jatimprov. go.id). Indonesia adalah salah satu negara penghasil tembakau yang menempati urutan ke 5 dunia dengan jumlah produksi tembakau sebesar 135.678 ton, atau sekitar $1.9 \%$ dari total produksi tembakau dunia (IAKMI, 2014). Di Indonesia, tembakau dihasilkan dari 3 kelompok, yakni Perkebunan Rakyat

\footnotetext{
Article History:

Received: Januari 2019; Accepted: Februari 2019

ISSN: 2502-5325 (Online) Terakreditasi Peringkat 4 oleh Kementerian Riset, Teknologi dan Pendidikan Tinggi (ARJUNA) berdasarkan Keputusan Direktur Jenderal Penguatan Riset dan Pengembangan Nomor: 21/E/KPT/2018 tanggal 9 Juli 2018
}

(PR), Perkebunan Besar Negera (PTPN), dan Perkebunan Besar Swasta (PBS). Mayoritas tembakau dihasilkan dari perkebunan rakyat, dimana sebagai penghasil terbesar tembakau di Indonesia adalah Provinsi Jawa Timur, dengan nilai produksi tembakau dari perkebunan rakyat sebesar 99.531 ton (2016) dan 100.052 ton (2017). Di wilayah Jawa Timur, Madura merupakan penghasil tembakau terbesar jika dibandingkan dengan daerah lain di Jawa Timur. Pada tahun 2015, tercatat jumlah produksi tembakau di Madura sebesar 24.241

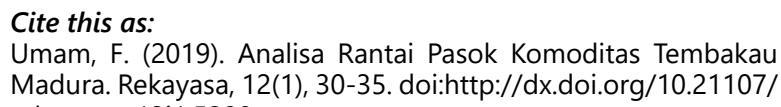

Umam, F. (2019). Analisa Rantai Pasok Komoditas Tembakau Madura. Rekayasa, 12(1), 30-35. doi:http://dx.doi.org/10.21107/ rekayasa.v12i1.5298

(C) 2019 Universitas Trunojoyo Madura 
ton yang dihasilkan dari 3 wilayah kabupaten, yakni Pamekasan (14.437 ton), Sampang (1.764 ton), Sumenep (8.039 ton) (http://ditjenbun.pertanian.go.id).

Komoditas tembakau dipasarkan sebagian besar kepada industri rokok nasional dan juga dijual ke pasar ekspor. Pada kenyataannya, dalam tata niaga tembakau, untuk memenuhi kebutuhan nasional, petani berada pada posisi tawar yang rendah. Posisi petani sebagai produsen, petani tidak bisa menentukan harga. Harga ditentukan oleh pabrik rokok kemudian turun ke pedagang besar, rayon, pengumpul, pengolah sampai petani. Di setiap simpul rantai penjualan, pelaku tata niaga mengambil margin keuntungan masing-masing. Dengan pola ini yang mengambil keuntungan paling banyak adalah pelaku tata niaga intermediate trader (pedagang besar, rayon, pengumpul), sedangkan petani posisinya lemah (2). Sedangkan, untuk tata niaga tembakau di Madura, Jawa Timur, mekanismenya lebih panjang. Yang lebih berperan dalam menentukan harga tembakau adalah bandol atau juragan. Disamping itu, di Madura masih belum ada asosiasi petani tembakau yang mampu memperjuangkan aspirasi petani (Jayadi, 2014). Bentuk perdagangan tembakau pada sistem tata niaga yang ada hingga saat ini, sifatnya masih konvensional dengan cara pembeli bertemu penjualnya secara langsung atau melalui telefon (jika sebelumnya sudah mengenal). Meskipun demikian, pembeli (industri) tidak membeli (melakukan transaksi) secara langsung kepada petani, melainkan kepada intermediate trader.

Perkembangan teknologi informasi saat ini semakin pesat, dan tidak hanya menyentuh pada sektor industri manufaktur saja, melainkan juga sudah diterapkan pada ektor industri lainnya (kesehatan, perbankan, perdagangan, dan industri lainnya) untuk mendukung proses bisnisnya. Salah satu bentuk terapan teknologi informasi pada dunia perdagangan yaitu berupa sistem e-commerse (perdagangan online). Salah satu keunggulan dari perdagangan online yaitu penjual mampu menjangkau konsumennya lebih luas dan lebih cepat (Didi, 2000). Pada saat ini, semakin banyak perusahaan yang membuat marketplace dalam tata niaga perdagangan. Marketplace merupakan suatu media online (virtual) yang dibuat sebagai tempat bertemunya antara penjual dan pembeli untuk melakukan transaksi penjualan barang/jasa (Philippe dan Adrien, 2010). Di Indonesia telah ada beberapa marketplace, seperti Lazada, Tokopedia, Bukalapak, dan yang lainnya. Keberadaan marketplace ini terbukti sangat membantu penjual maupun pembeli. Dengan melihat kondisi tata niaga penjualan komoditas tembakau (khususnya tembakau madura), serta melihat hasil terapan teknologi informasi pada dunia perdagangan, maka pada penelitian ini ingin dikaji perbaikan tata niaga penjualan komoditas tembakau madura.

\section{METODE PENELITIAN}

Metode yang digunakan untuk mendapatkan data dalam penelitian ini yaitu Focus Group Discussion (FGD) dan dengan melakukan wawancara. Penggunaan metode FGD ini bertujuan untuk menggali dan mendapatkan berbagai informasi tentang masalah tertentu dengan penjelasan (sumber) yang berbeda (De Luca, dkk., 2015). FGD dilakukan oleh tim peneliti dengan sejumlah pihak terkait, diantara yaitu akademisi, unsur pemerintah daerah dan perwakilan dari unsur petani. Tujuan dilakukannya FGD ini untuk menggali informasi yang terkait dengan kondisi petani tembakau, permasalahan yang dihadapi oleh petani komoditas tembakau, peran dari masing-masing unsur yang selama ini telah dilakukan, mekanisme distribusi komoditas tembakau, tata niaga dan berbagai kajian lain yang terkait dengan komoditas tembakau.

Selain melakukan FGD, tim peneliti juga melakukan wawancara kepada sejumlah responden lain, yakni petani tembakau dan intermediate trader (pengepul, bandol). Tujuan dari wawancara ini yaitu untuk mendapatkan data-data yang lebih detail tentang budidaya tanaman tembakau, deskripsi produk tembakau, pengolahan pasca panen, mekanisme penjualan/ distribusi produk tembakau dan harga jualnya, serta informasi lain yang terkait. Setelah mendapatkan data, kemudian dibuat analisa SWOT dan analisa rantai distribusi dan pasok. Metode SWOT digunakan untuk mengidentifikasi kondisi internal yakni kekuatan (strength), dan kelemahan (weakness), sedangkan kondisi eksternal menggambarkan peluang (opportunity) dan ancaman (threat) (Emet, 2017). Berdasarkan hasil dari analisa SWOT, akan diperoleh beberapa strategi dari pemanfaatan kekuatan yang dimiliki untuk menangkap sejumlah peluang yang ada, dan strategi untuk meminimalkan/mengatasi berbagai kelemahan yang saat ini dalam menghadapi segala ancaman yang mungkin terjadi.

Untuk mendapatkan gambaran analisa sistem distribusi komoditas tembakau madura, maka selain menggunakan analisa SWOT, peneliti juga menggunakan analisa rantai distribusi/ pasok. Analisa rantai distribusi dibuat dengan tujuan untuk memberikan informasi distribusi komoditas produk tembakau madura, mulai dari hulu hingga ke hilir atau mulai dari petani hingga ke konsumen akhir. Informasi ini men- 
cakup kapasitas produksi petani tembakau harga jual tembakau di setiap titik distribusi, peran dari masing-masing pelaku distribusi, sistem jual beli, mekanisme perpindahan komoditas (transportasi), dan berbagai informasi lainnya.

\section{HASIL DAN PEMBAHASAN}

Berdasarkan hasil proses FGD dan wawancara, dapat dipetakan kondisi tembakau Madura dengan analisa SWOT. Hasilnya sebagai berikut:

Kekuatan (Strength):

1. Kualitas tembakau madura relatif lebih baik dibandingkan dengan tambakau dari daerah lain di indonesia. Pada beberapa daerah di Madura, tembakaunya memiliki aroma yang khas, kandungan kadar gula dan nikotin yang lebih tinggi dibanding tembakau dari daeah lain (http://balittas. litbang. pertanian.go.id).

2. Potensi lahan untuk peningkatan volume produksi tembakau masih besar.

3. Masyarakat petani tembakau sudah familiar dengan sistem tanam (produksi) tembakau.

4. Selama ini, konsumen akhir dari komoditas tembakau madura adalah sebagian besar industri besar di Indonesia atau bahkan di pasar ekspor.

Kelemahan (Weakness):

1. Harga jual tembakau madura dari petani masih sangat rendah karena jaringan tata niaga yang panjang.

2. Meskipun sudah sangat lama melakukan budidaya tembakau, namun teknik budidaya yang dilakukan hingga saat ini masih monoton (belum profesional) dengan berbagai kelemahan yang ada, seperti belum menerapkan kendali mutu pada sistem budidaya sebelum dan pasca panen.

3. Petani tembakau belum memiliki kemampuan manajerial penjualan yang baik, sehingga posisi kekuatan dagangnya masih lemah. Akibatnya, peran bandol (tengkulak) lebih mononjol dalam memainkan harga komoditas tembakau.

4. Peran lembaga pemerintah dan akademisi masih belum terasa signifikan dampaknya bagi petani tembakau. Hal ini terlihat dari kondisi petani tembakau dari tahun ke tahun belum mengalami perubahan perbaikan kondisi ekonomi yang signifikan.

Peluang (Opportunity):

1. Pasar komoditas tembakau masih besar. Kebutuhan ekspor dan industri nasional masih besar.

2. Komoditas tembakau madura menjadi salah satu andalan komoditas pulau mad- ura, sehingga pemerintahan di kabupaten Madura memberikan dukungan pengembangan ekonomi pada sektor tembakau.

3. Komoditas tembakau menjadi salah satu komoditas pertanian yang menjadi target pengembangan bagi Universitas Trunojoyo Madura melalui program Enam Sektor.

4. Sistem perdagangan bebas sudah berjalan, memberikan kesempatan untuk bisa mendapatkan komsumen lebih mudah dan lebih banyak.

5. Perkembangan teknologi informasi yang semakin pesat, salah satunya dalam bidang e-commerce yang mampu meningkatkan keuntungan dan menekan biaya dalam sistem perdagangan.

Ancaman (Threat):

1. Keberadaan jaringan intermediate trader (tengkulak, bandol, juragan) yang sudah ada sejak lama dan selama ini masih eksis, bahkan cenderung kuat dan bertambah jumlahnya.

2. Regulasi yang semakin ketat tentang standar mutu tembakau.

3. Kondisi cuaca/iklim di indonesia (madura) yang semakin sulit diprediksi. Masa musim kemarau dan musim penghujan setiap tahunnya semakin sulit diprediksi. Hal ini bisa menyebabkan terjadinya resiko gagal panen.

4. Semakin mahalnya biaya perawatan penanaman komoditas tembakau (harga bibit, pupuk, ancaman hama, tenaga kerja).

\section{Aliran Rantai Pasok Tembakau Madura}

Petani tembakau di pulau Madura hingga saat ini belum mendapakan harga jual komoditasnya dengan baik. Terjadi selisih yang besar antara harga jual dari petani dengan harga beli dari konsumen akhir (industri). Terjadinya selisih harga ini dikarenakan panjangnya rantai distribusi atau rantai pasok komoditas tembakau madura. Pada gambar 1, terlihat distribusi penjualan tembakau Madura mulai dari hilir (petani tembakau) hingga hulu (konsumen akhir; pabrik).

Sebagai konsumen terbesar tembakau Madura hingga saat ini adalah pabrik skala besar/ sedang, seperti PT. Gudang Garam, PT. Sampoerna, dan Industri besar lainnya. Sebanyak kurang lebih $90 \%$ hasil panen petani tembakau Madura dibeli oleh industri besar tersebut.

Jika diamati, antara hulu hingga hilir, harga tembakau paling tidak mengalami 3 sampai 4 kali kenaikan harga penjualan. Kondisi ini yang menyebabkan ekonomi petani tembakau madura belum mengalami kenaikan yang signifikan. Justru para intermediate trader (seperti pengepul, bandol, juragan, pengecer, 


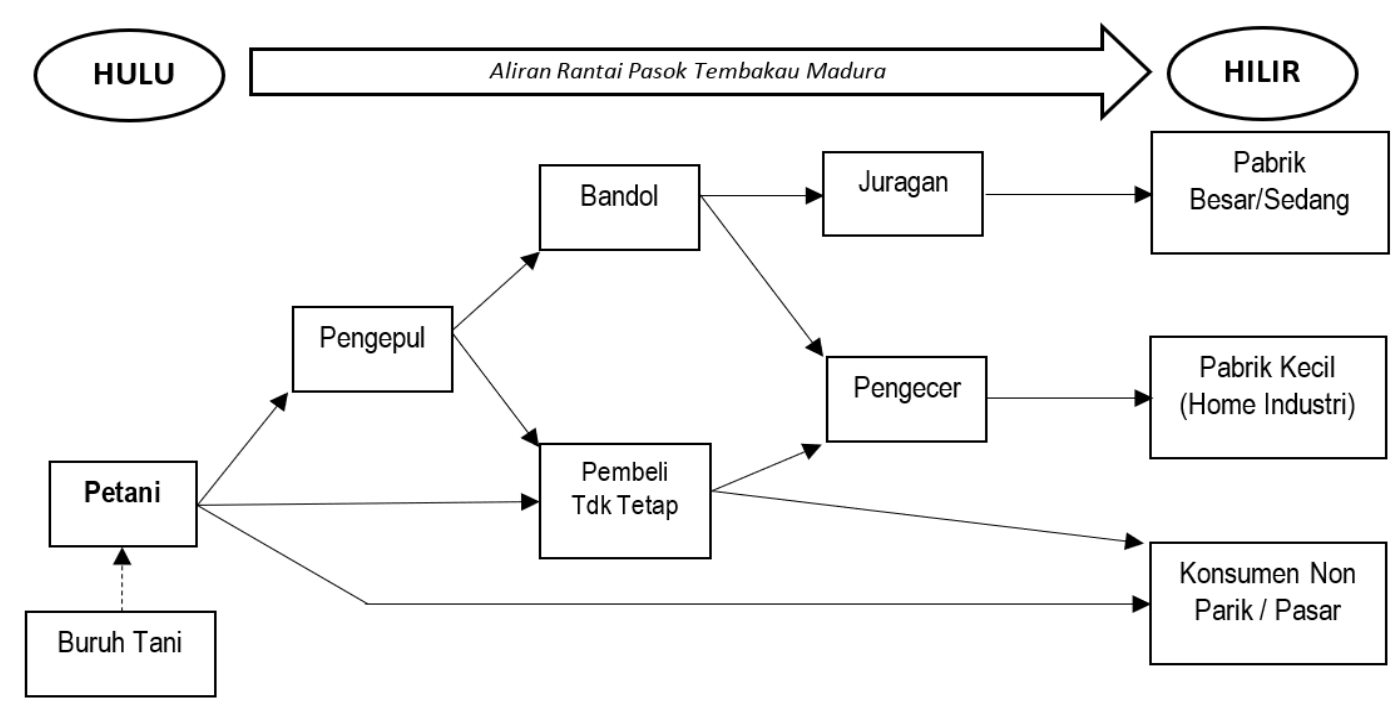

Gambar 1 Design network rantai pasok komoditas tembakau madura

pembeli tidak tetap) yang mendapatkan keuntungan lebih besar dibandingkan petani tembakau, karena para intermediate trader mengambil keuntungan sendiri-sendiri dan ini tidak mengeluarkan biaya tanam tembakau beserta resiko gagal panen. Selain itu, intermediate trader ini memiliki knowledge tentang manajemen pemasaran, kemampuan komunikasi, jaringan akses pemasaran, fasilitas dan penguasaan teknologi yang lebih baik dibandingkan dengan para petani tembakau.

\section{Rakayasa Rantai Pasok Tembakau Madura}

Kondisi panjangnya rantai pasok komoditas petani tembakau Madura, menyebabkan harga jual yang rendah pada tingkat petani. Oleh karena itu, perlu adanya upaya untuk memperpendek rantai pasok tersebut.

Pada saat ini pedagang semakin banyak yang memanfaatkan sistem online dalam memasarkan produknya. Salah satu kelebihan sistem perdagangan online yaitu kepuasan konsumen. Konsumen bisa mendapatkan informasi produk komoditas dengan lebih mudah (jenis produk, harga, kualitas, dan informasi lain). Sistem yang seperti ini, memudahkan produsen untuk bisa menjual produknya langsung kepada konsumennya (Abdul, 2016). Kelebihan lainnya yaitu dengan e-commerce (sistem penjualan online), penjual terbukti mampu meningkatkan jumlah pelanggan dan memperluas areal pemasaran produk $(\mathrm{Hi}-$ mawan, dkk., 2014).

Petani tembakau di Madura, hingga saat ini belum memanfaatkan teknologi penjualan online secara maksimal. Hal ini dikarenakan masih lemahnya pengetahuan petani tembakau tentang teknologi tersebut. Oleh kare- na itu, dibutuhkan suatu pendekatan yang mampu meningkatkan perbaikan kondisi ekonomi petani tembakau dalam rantai pasok perdagangan komoditas tembakau madura. Berdasarkan hasil analisa SWOT dan rantai pasok tata niaga tembakau Madura, maka bentuk terapan teknologi yang bisa digunakan untuk memperpendek rantai pasok tersebut tata niaga yaitu melalui rekayasa dengan menggunakan teknologi e-commerce yang berupa sistem penjualan online yang menghubungkan antara petani dengan pembeli akhir (sektor hilir) [gambar 2]. Sistem ini berupa marketplace khusus untuk komoditas tembakau. Tidak menutup kemungkinan, marketplace ini nantinya bisa dikembangkan untuk komoditas perkebunan dan pertanian yang lainnya.

Dalam model Qudrable Helix, terdapat integrasi empat komponen, yakni Pemerintah (Government), Pelaku Bisnis (Businessman), Akademisi (Academician), dan Masyarakat (Civil Society). Sinergi yang baik antar komponen model mampu meningkatkan kesinambungan ekonomi (Anderson, dkk., 2017). Universitas Trunojoyo Madura, selaku komponen akademisi berperan dalam proses transfer pengetahuan dan teknologi kepada petani tembakau Madura. Penciptaan pasar online yang berupa marketplace akan dilakukan oleh Universitas Trunojoyo Madura. Marketplace akan di desain berdasarkan kebutuhan petani (penjual) dan pembeli. Sistem marketplace ini tidak dijalankan sepenuhnya oleh petani tembakau madura. Akademisi (Universitas Trunojoyo Madura) ikut berperan dalam operasional sistem tersebut untuk membantu petani dalam manajerial penjualan komoditas. Untuk menciptakan sistem pen- 


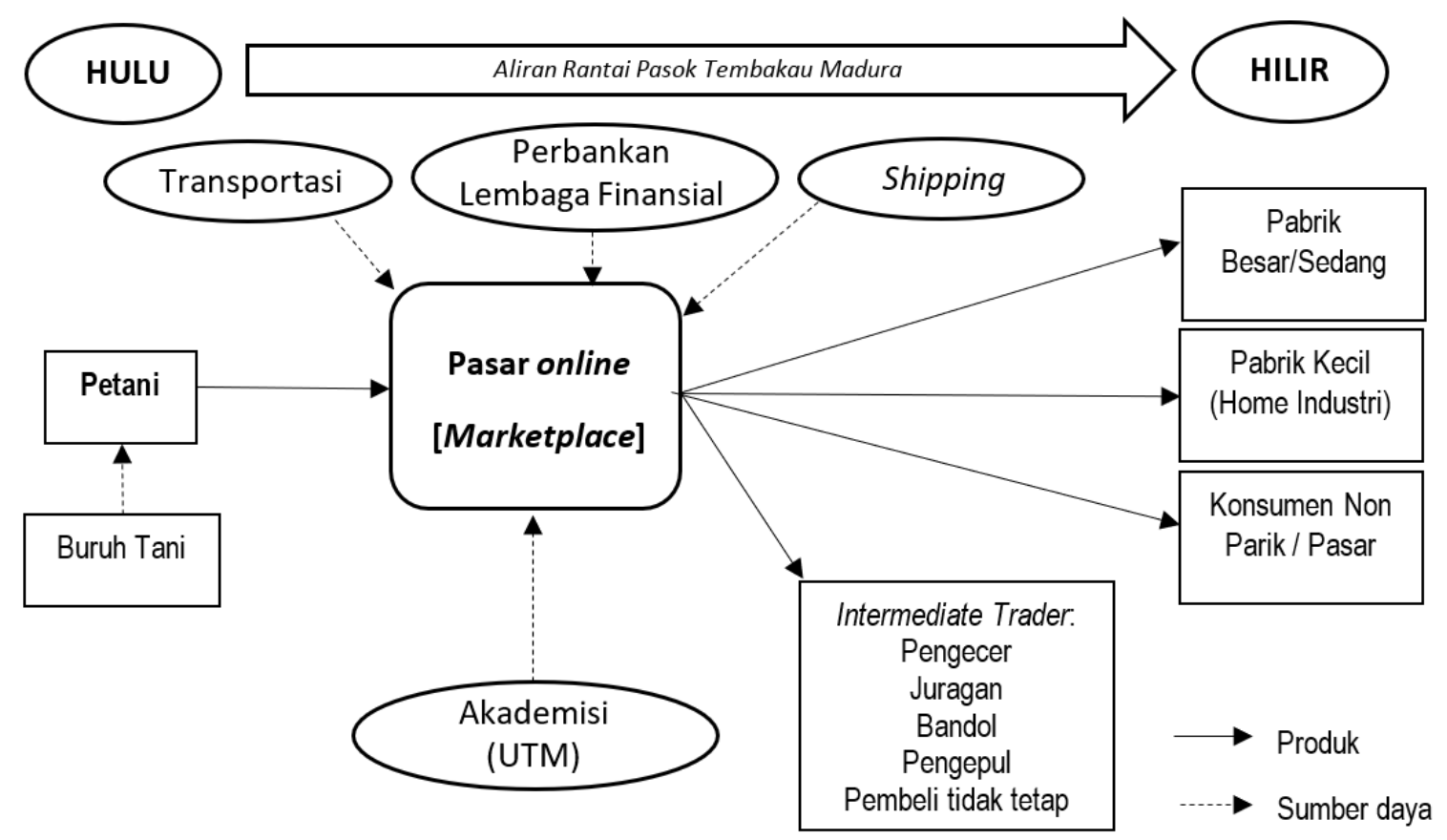

Gambar 2 Usulan design network rantai pasok komoditas tembakau madura

jualan yang lebih baik dan secure, maka dibutuhkan kerja sama dengan pihak lain dalam mekanisme supply komoditas, yakni dengan pihak transportasi, shipping, dan lembaga keuangan. Peran dari lembaga keuangan adalah sebagai penjamin transaksi pembayaran dari konsumen kepada produsen (petani), sedangkan shipping dan transportasi berperan dalam pengiriman komoditas dari petani tembakau kepada pembeli. Ini akan memudahkan konsumen maupun penjual dalam hal pilihan moda pengiriman barang.

\section{SIMPULAN DAN REKOMENDASI}

Sistem penjualan komoditas tembakau madura yang terjadi hingga saat ini belum memberikan keuntungan yang maksimal bagi

\section{DAFTAR PUSTAKA}

Rochyatun, E. (2007). Pemantauan Kadar Logam Berat Dalam Sedimen Di Perairan Teluk Jakarta. Jurnal Makara Sains. Vol. 11 No. 1, 28-36.

Abdul G. K., (2016). Electronic Commerce: A Study on Benefits and Challenges in an Emerging Economy, Global Journal of Management and Business Research: B Economics and Commerce, Volume 16 Issue 1 Version 1.0. petani tembakau. Hal ini disebabkan panjangnya rantai distribusi/pasok dalam sistem penjualan tersebut. Sistem seperti ini lebih banyak memberikan keuntungan yang lebih besar kepada pihak intermediate trader. Untuk memperbaiki sistem penjualan ini, dibutuhkan kerja sama dengan pihak lain, utamanya adalah pihak akademisi. Melalui akademisi, bisa dikembangkan sistem penjualan online dengan penciptaan marketplace yang dikembangkan dan dikelola oleh akademisi. Tujuannya yaitu untuk memotong keberadaan rantai intermediate trader.

Penelitian ini diharapkan bisa dikembangkan pada tahap selanjutnya dengan cara merealisasikan marketplace tersebut dan kemudian bisa diimplementasi-kan kepada petani tembakau madura.

Anderson G., Carla M., Ricardo G. R., Carla S. M., Carmem T. L, (2017). A quadruple helix model of entrepreneurship, innovation and stages of economic development, Review of International Business and Strategy, Vol. 27 Issue: 2, pp.261-282.

De Luca, A. I., lofrida, N., Strano, A., Falcone, G., \& Gulisano, G. (2015). Social life cycle assessment and participatory approaches: A methodological proposal applied to citrus farming in 
Southern Italy. Integrated environmental assessment and management, 11(3), 383-396.

Emet G., Merba TAT. (2017). SWOT Analysis: A Theoretical Review, The Journal of International Social Research, Vol.10, Issue 51.

Didi A. (2000). Potensi Manfaat dan Problem di E-Commerse, Jurnal Ekonomi dan Bisnis Indonesia, Vol.15, No.3.

Himawan, Asep S., Sugeng S., (2014). Analisa dan Perancangan Sistem Informasi Penjualan Online (E-Commerce) pada CV Selaras Batik Menggunakan Analisis Deskriptif, Scientific Journal of Informatics, Vol. 1, No. 1.

http://ditjenbun.pertanian.go.id. Statistik Perkebunan Indonesia, 2015-2017, Tembakau. https://disbun.jatimprov.go.id/arealtanaman. php.

http://balittas.litbang.pertanian.go.id/images/Monograf/madura/Mutu-tembakau-madura.pdf. Samsuri T., Abi D.H., Mutu Tembakau Madura.

IAKMI (2014). Fakta Tembakau dan Permasalahannya, Buku Bunga Rampai, Edisi V Tobacco Control and Support Center.

Jayadi A., (2014). Sengsara di Timur Jawa: Laporan Jurnalisme Investigatif atas Sistem Tata Niaga Tembakau di Pamekasan, Sumenep dan Jember. Seminar Tobacco Marketing Chain: Bargaining Power of Tobacco Farmers and the Government Role. Lembaga Demografi FEUI.

Philippe C., Adrien N., (2010). Marketplace: The Future of E-Commerce, Mirakl. 